\title{
Aspirin reduces the apoptotic effect of etoposide via Akt activation and up-regulation of $\mathrm{p}^{2}{ }^{\text {cip }}$
}

\author{
XIAOCHENG FENG ${ }^{1,2}$, BIN LU ${ }^{1}$, YINGYING XU ${ }^{2}$, QIN LI ${ }^{1}$, WENBAI ZHOU ${ }^{1}$, ZHIHONG YANG ${ }^{1}$, \\ ZENG YANG $^{1}$, WEIWEI ZHAO ${ }^{1}$, ZONGHOU SHEN $^{2}$ and RENMING HU ${ }^{1}$ \\ ${ }^{1}$ Department of Endocrinology and Metabolism, Huashan Hospital, Institute of Endocrinology and Diabetology, \\ Department of Medicine, Shanghai Medical College, ${ }^{2}$ Department of Biochemistry and Molecular \\ Biology, Shanghai Medical College, Fudan University, Shanghai, P.R. China
}

Received April 1, 2011; Accepted May 13, 2011

DOI: $10.3892 / \mathrm{ijmm} .2011 .713$

\begin{abstract}
Previous studies on the apoptotic effect of aspirin mainly focus on colorectal cancer and breast carcinoma. Few studies have been designed to explore the effect of aspirin on hepatocellular carcinoma. In the present study, we observed that aspirin caused G0/G1 phase cell cycle arrest and reduced etoposide induced caspase-3 activation in hepatocellular carcinoma G2 (HepG2) cells. Further investigation demonstrated that aspirin notably enhanced the activity of Akt and ERK1/2. Blocking the activation of Akt by the PI3-K-selective inhibitor wortmannin abrogated the anti-apoptotic effect of aspirin while the MEK inhibitor U0126 did not. p21 $1^{\text {cip }}$, an important substrate of Akt, is involved in the regulation of cell cycle arrest and apoptosis. Our data showed that the protein expression and ser146 phosphorylation levels of p21 ${ }^{\text {cip }}$ were significantly increased after treatment with aspirin, whereas p53 or p27 showed no change. The increase of p21 cip protein levels was also scavenged by wortmannin but not by U0126. Moreover, reduction of caspase- 3 activity induced by aspirin was attenuated by silencing $\mathrm{p} 21^{\text {cip }}$ expression. These results indicated that the anti-apoptotic effect of aspirin was dependent on activation of Akt which inhibited cell apoptosis by up-regulating p $21^{\text {cip }}$ and blocking caspase- 3 activation. These findings could have clinical relevance in anticancer therapy and aspirin co-treatment of human malignancies.
\end{abstract}

\section{Introduction}

Hepatocellular carcinoma is a major health threat in China, which ranks third among all malignancies both in incidence and mortality and accounts for about $42.5 \%$ of the total incidence worldwide $(1,2)$. Previous studies have shown that

Correspondence to: Dr Zonghou Shen, Department of Biochemistry and Molecular Biology, Shanghai Medical College, Fudan University, 138 Yixueyuan Road, Shanghai, P.R. China

E-mail: zonghoushen@hotmail.com

Key words: aspirin, apoptosis, Akt, p21 cip cyclooxygenase-2 (COX-2) is highly expressed in hepatocellular carcinoma and its cell lines $(3,4)$. COX-2 selective antagonists, NS-398 and celecoxib, inhibit hepatocellar carcinoma cell proliferation and induce cell apoptosis via COX-dependent and COX-independent pathways $(3,4)$.

Acetyl salicylic acid (aspirin, ASA), a non-selective COX inhibitor, has been widely used as an antipyretic and analgesic agent. Clinical observations and epidemiological research studies have found that prolonged use of aspirin reduces the risk of several cancers, such as colon, breast and lung cancers forth (5-7). In vitro and animal studies have demonstrated that aspirin can induce cell apoptosis through COX-dependent and COX-independent pathways. The COX-independent effects include alteration of gene transcription $(8,9)$, inhibition of proteasome function (10), cell cycle arrest, modulation of several protein kinases and other molecular signaling pathways $(11,12)$ and down-regulation of nuclear factor- $\mathrm{B}(\mathrm{NF}-\kappa \mathrm{B})$ activity by preventing phosphorylation and degradation of the inhibitory subunit I $\mathrm{B}(13,14)$. All of these effects of aspirin are mainly observed in colon, breast and lung cancer. Few studies have examined the effects of aspirin on hepatocarcinomas.

To study the potential effect of aspirin on hepatocellular carcinoma proliferation and apoptosis, hepatocellular carcinoma G2 (HepG2) cells were treated with etoposide and aspirin alone and in combination. The data showed that aspirin did not enhance the apoptotic effect of etoposide whereas it reduced the anti-cancer effect of vp16. The potential mechanism of how aspirin attenuates the anti-cancer effects of etoposide need further investigation.

\section{Materials and methods}

Reagents. Aspirin (ASA), etoposide (vp16) and the tetrazolium salt (MTT) were purchased from Sigma (St. Louis, MO). Propidium iodide (PI) and the Annexin V-FITC/PI Apoptosis Detection kit were obtained from Invitrogen (Carlsbad, CA, USA). The CleavLite Caspase-3 Activity Assay kit was purchased from Millipore Corporation (Billerica, MA, USA). p21 ${ }^{\text {cip }}$, phospho-p21 ${ }^{\text {cip }}$ (ser146), phospho-ERK1/2, ERK1/2, phospho-Akt (ser473), Akt, p27 and p53 antibodies (polyclonal rabbit anti-human) were purchased from Cell Signaling Technology (Danvers, MA). The monoclonal mouse $\beta$-actin 
antibodies was purchased from Santa Cruz Biotechnology (Santa Cruz, CA). Small interference RNA for p21 and the negative control was obtained from Santa Cruz Biotechnology. Wortmannin and U0126 were purchased from Cell Signaling Technology. The real-time PCR Master Mix kit and the Reverse Tra Ace kit were purchased from Takara (Dalian, China).

Cell culture and treatment. HepG2 cells were obtained from the Institute of Cell and Biochemistry Research of the Chinese Academy of Science. HepG2 cells were cultured in DMEM medium containing $10 \%$ fetal bovine serum at $37^{\circ} \mathrm{C}$, in a humidified atmosphere of $5 \% \mathrm{CO}_{2}$, supplemented with penicillin $(100 \mathrm{UI} / \mathrm{ml})$ and streptomycin $(100 \mu \mathrm{g} / \mathrm{ml})$.

Before treatment, cells were seeded into dishes and grew for at least $12 \mathrm{~h}$. When the cell came to $40-50 \%$ confluence, drugs were added into the refreshed medium containing $1 \%$ serum. Before adding vp16, cells were incubated with ASA (dissolved into the $1 \%$ serum medium and filtered before use) for $1 \mathrm{~h}$ with fresh medium containing $1 \%$ serum. Wortmannin, U0126 and vp16 were dissolved in DMSO and stored at $-20^{\circ} \mathrm{C}$.

Cell apoptosis analysis. HepG2 cells were treated with ASA and vp16 alone and in combination for $24 \mathrm{~h}$ as follows: control (DMSO), $5 \mathrm{mM}$ ASA, $20 \mu \mathrm{M}$ vp16, $1 \mathrm{mM}$ ASA $+20 \mu \mathrm{M}$ vp16, $3 \mathrm{mM}$ ASA + $20 \mu \mathrm{M}$ vp16, $5 \mathrm{mM}$ ASA + $20 \mu \mathrm{M}$ vp16. Before administering vp16, the medium was refreshed with the new medium (containing 1\% serum and various concentrations of ASA) and incubated for $1 \mathrm{~h}$. After treatment with vp16 for another $23 \mathrm{~h}$, cells were collected and stained with Annexin V-FITC and PI according to the manufacturer's protocol. Cell apoptosis was examined by a FACS cytometer.

Assessment of caspase-3 catalytic activity. Caspase-3 activity was determined by the CleavLite Caspase- 3 Activity Assay kit, according to the manufacturer's instructions. HepG2 cells were cultured in 6-well plates. After treatment, the cells were scraped off in PBS and collected by centrifugation at $1,000 \mathrm{x} \mathrm{g}$ for $10 \mathrm{~min}$ at $4^{\circ} \mathrm{C}$. The cells were resuspended to $1 \times 10^{5} / \mathrm{ml}$ with ice-cold cell lysis buffer, incubated for $5 \mathrm{~min}$ on ice, and centrifuged at $10,000 \mathrm{x}$ g for $10 \mathrm{~min}$ at $4^{\circ} \mathrm{C}$. The protein concentration in the supernatant was determined using the Improved Lowry method. The cell lysate $(50 \mu \mathrm{l}), 2 \mathrm{X}$ reaction buffer $(50 \mu \mathrm{l})$, and caspase-3 fluorogenic substrate ( $5 \mu$ l DEVD-AFC) were loaded into a 96 -well plate and incubated at $37^{\circ} \mathrm{C}$ in the dark for $1 \mathrm{~h}$. The plate was read on a fluorescence plate reader setting at an emission of $505 \mathrm{~nm}$ (to detect the fluorescent reporter molecule AFC which represents caspase-3 activity).

MTT assay. Cells at 30-40\% confluence were incubated with various concentrations of aspirin in 96-well plates. After culturing with $1 \%$ serum medium for 24 or $48 \mathrm{~h}$, the cell proliferation was evaluated by measuring the mitochondriadependent conversion of the tetrazolium salt, MTT (Sigma).

Cell cycle assay. Cells were collected by trypsinization and fixed in ice-cold $70 \%$ ethanol at $-20^{\circ} \mathrm{C}$ overnight. The cells were washed twice with ice-cold PBS and resuspended in $500 \mu \mathrm{l}$ PBS containing $100 \mathrm{U} / \mathrm{ml}$ RNaseA and propidium iodide $(20 \mu \mathrm{g} / \mathrm{ml})$, and then incubated at room temperature for 30 min and analyzed by a FACS cytometer.
Western blot analysis. Whole cell extracts were prepared by lysing cells with 1X SDS lysis buffer with $0.5 \mathrm{mM}$ phenylmethylsulfonyl fluoride (PMSF), $1 \mathrm{mM}$ dithiothreitol, $10 \mathrm{mM}$ $\mathrm{NaF}, 2 \mathrm{mM} \mathrm{Na} \mathrm{VO}_{4}$ and $5 \mathrm{mg} / \mathrm{ml}$ leupeptin. Nuclear and cytoplasmic extracts were prepared according to previously described methods (15). Protein samples were quantified with the Improved Lowry method and then applied to $10 \%$ SDS-PAGE gels. After electrophoresis, proteins were blotted to PVDF membranes and then blocked with 5\% skim milk powder containing $0.1 \%$ Tween-20 for $1 \mathrm{~h}$ at room temperature. The membranes were subsequently incubated with primary antibody at $4^{\circ} \mathrm{C}$ overnight. After rinsing with TBST $(0.1 \%$ Tween-20, TBS) 3 times, the PVDF membranes were incubated with horseradish peroxidase-conjugated secondary antibody $(1: 1,000)$ at room temperature for $1 \mathrm{~h}$. Positive bands were detected using ECL reagents (Pierce).

Real-time-PCR. Total-RNA was extracted from HepG2 cells by TRIzol (Invitrogen) reagent and reverse-transcribed into cDNA. Real-time PCR was performed with 3 min incubation at $95^{\circ} \mathrm{C}$ and 40 amplification cycles $\left(95^{\circ} \mathrm{C}, 10 \mathrm{sec} ; 56^{\circ} \mathrm{C}\right.$, $\left.15 \mathrm{sec} ; 72^{\circ} \mathrm{C}, 35 \mathrm{sec}\right)$. $\beta$-actin was used as internal control. The amplification and data acquisition were run on a real-time PCR system (ABI PRISM 7500, Applied Biosystems, Foster City, CA, USA) with a SYBR-Green PCR master mix. The primers used were: $\beta$-actin: forward, 5'-ACCCACACTGTG CCCATCTA-3' and reverse, 5'-GCCACAGGATTCCATAC CCA-3'; p21 ${ }^{\text {cip }}$ : forward, 5'-AGAGTGCAAGACAGCGACAA GG-3' and reverse, 5'-GGTGATGTCCGACCTGTTCCG-3'.

Transfection of $21^{\text {cip }}$ siRNA. After plating for $12 \mathrm{~h}$, cells at $40 \%$ confluence were transfected with $\mathrm{p} 21^{\text {cip }}$ siRNA (final concentration $40 \mathrm{nM}$ ) using lipofectin2000 transfection regent. After transfected for $6 \mathrm{~h}$, the medium was refreshed and cultured for another $18 \mathrm{~h}$. Then the cells were treated with vp16 and aspirin alone and in combination as above. Transfection was performed following the Lipofectamine 2000 manufacturer's instructions.

Statistical analysis. The results were presented as the mean \pm standard error (SE). The data were analyzed using one-way ANOVA with Bonferroni post-hoc tests for multiple comparisons. Simple pairwise comparisons were performed using the Student's t-test. A P-value $<0.05$ was considered statistically significant.

\section{Results}

Aspirin reduces the anti-cancer effect of vpl6 and induces cell cycle arrest. To evaluate the effect of ASA on hepatocellular carcinoma cell apoptosis, HepG2 cells were treated with ASA and vp16 alone and in combination for $24 \mathrm{~h}$ as discribed in Materials and methods. The apoptosis rate was analyzed by flow cytometer. Unexpectedly, compared to the vp16-treated group, the apoptosis rate was significantly decreased in the vp16 plus ASA (5 mM)-treated group (Fig. 1A and B). To confirm this result, the activity of caspase-3, an key executor in caspase-dependent apoptosis process, was examined by ELISA. In agreement with the results of the flow cytometry assay, caspase-3 activity was down-regulated in vp16 plus 
A
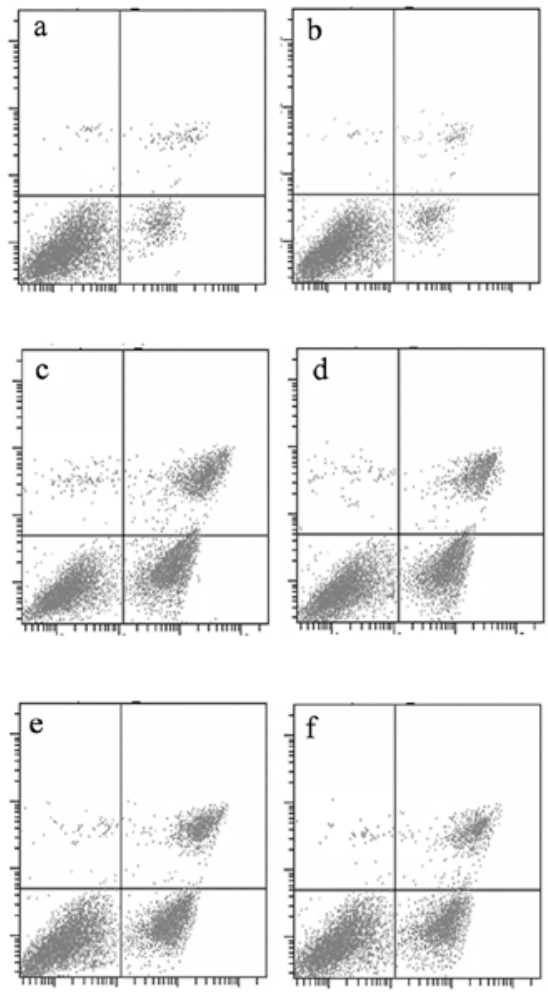

B

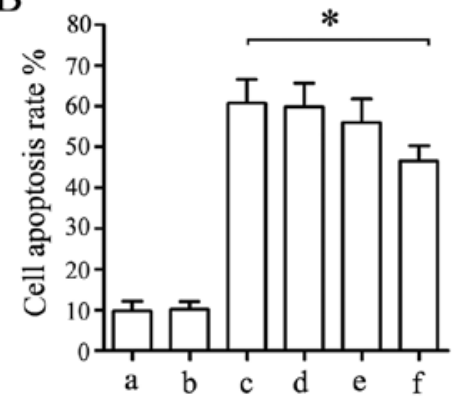

C

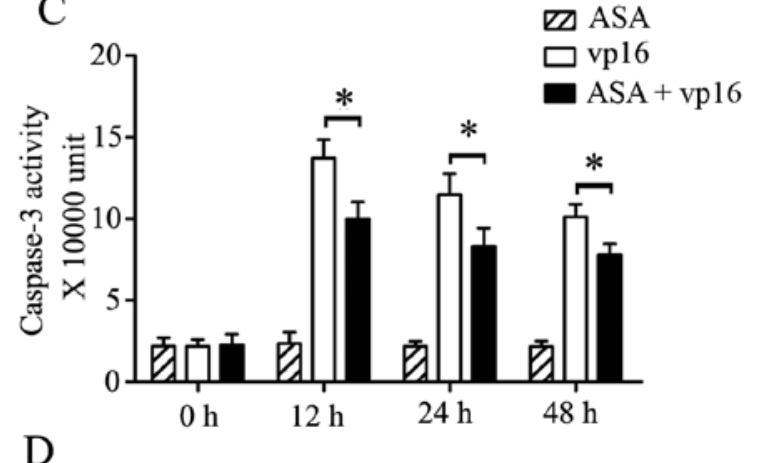

D

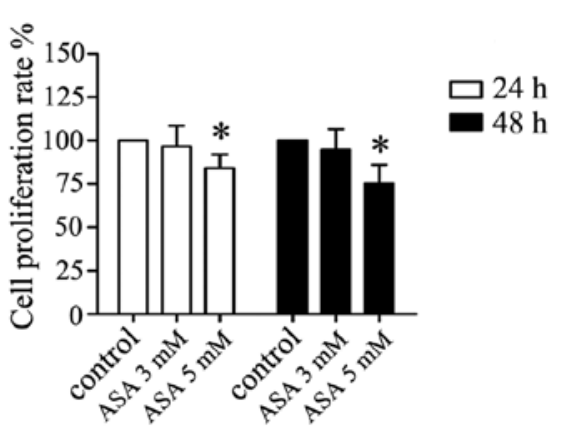

E
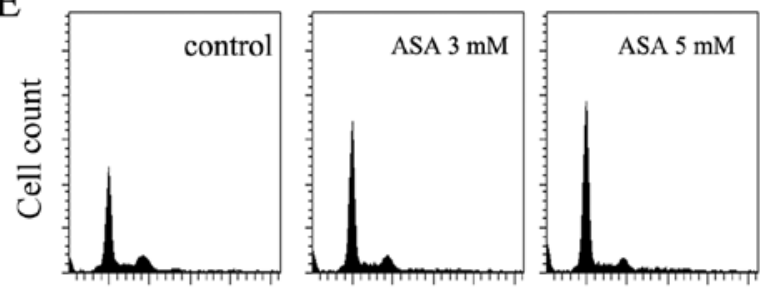

F

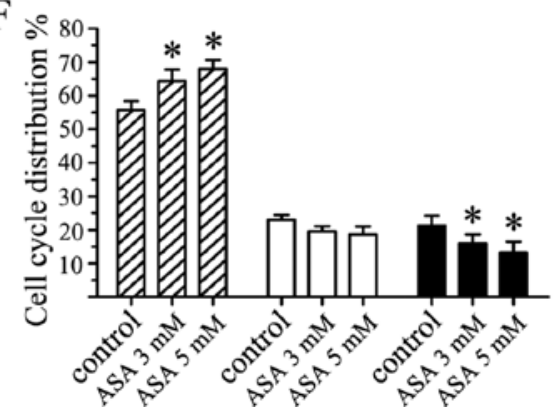

Figure 1. Effects of aspirin (ASA) on cell apoptosis, proliferation and cell cycle. (A) HepG2 cells were treated with ASA and vp16 alone and in combination for $24 \mathrm{~h}$ as follows: (a) DMSO, (b) $5 \mathrm{mM}$ ASA, (c) $20 \mu \mathrm{M} v 16$, (d) $1 \mathrm{mM} \mathrm{ASA}+20 \mu \mathrm{M} v 16$, (e) $3 \mathrm{mM} \mathrm{ASA}+20 \mu \mathrm{M} v 16$, (f) $5 \mathrm{mM}$ ASA $+20 \mu \mathrm{M} v 16$. The apoptosis rate was analyzed by FACS. (B) Data were calculated as the percentage of apoptotic cells. The values are presented as the mean \pm SE of three independent samples (t-test, $\left.{ }^{*} \mathrm{P}<0.05\right)$. (C) HepG2 cells were treated with ASA $(5 \mathrm{mM})$ and vp16 $(20 \mu \mathrm{M})$ alone or in combination for different lengths of time. Cells were harvested and caspase-3 activity was assayed by ELISA. The values are presented as the mean \pm SE of three independent experiments (t-test, ${ }^{*} \mathrm{P}<0.05$ ). (D) Cells were treated with ASA for 24 or $48 \mathrm{~h}$; the cells were mixed with MTT, and the MTT activity was measured. The cell proliferation rate (\%) was normalized to the control groups. The values are presented as the mean \pm SE of four independent experiments (one-way ANOVA, $\left.{ }^{*} \mathrm{P}<0.05\right)$. (E) After treatment with ASA $(5 \mathrm{mM})$ for 24 or $48 \mathrm{~h}$ with $1 \%$ serum, cells were harvested and stained with PI before FACS analysis. (F) Changes of the cell cycle distribution were calculated by the CellQuest software. The results are presented as the mean \pm SE of three independent experiments ("one-way ANOVA, P<0.05).

ASA (5 mM) group compared to the vp16 group (Fig. 1C). Moreover, ASA at $5 \mathrm{mM}$ inhibited the cell proliferation and induced G0/G1 cell arrest after 24 and $48 \mathrm{~h}$ treatment (Fig. 1D, $\mathrm{E}$ and $\mathrm{F}$ ). In addition, ASA at $5 \mathrm{mM}$ neither increased the cell apoptosis rate nor enhanced caspase-3 activity (Fig. 1A, B and C). Taken together, these results indicated that ASA was able to reduce the apoptotic effect of vp16 and to induce cell cycle arrest in the G0/G1 phase.

Aspirin decreases the apoptotic effect of vpl6 mainly through enhancing the activity of Akt. Akt and ERK1/2 are the key molecules in regulating cell proliferation, apoptosis, cell cycle and cell survival. The activity of Akt and ERK1/2 were examined by Western blot analysis. The phosphorylation levels of Akt (ser473) and ERK1/2 (thr202/tyr204) were greatly up-regulated after treatment with ASA for $24 \mathrm{~h}$ (Fig. 2A). To confirm this result, HepG2 cells were treated with ASA $(5 \mathrm{mM})$ for $0,5,10,15,30 \mathrm{~min}$. The phosphorylation levels of Akt and ERK were assayed as above and found to be significantly increased within 5 and 10 min respectively (Fig. 2B).

The PI3-K and MEK selective inhibitors, wortmannin and U0126, were used to determine whether the anti-apoptotic 

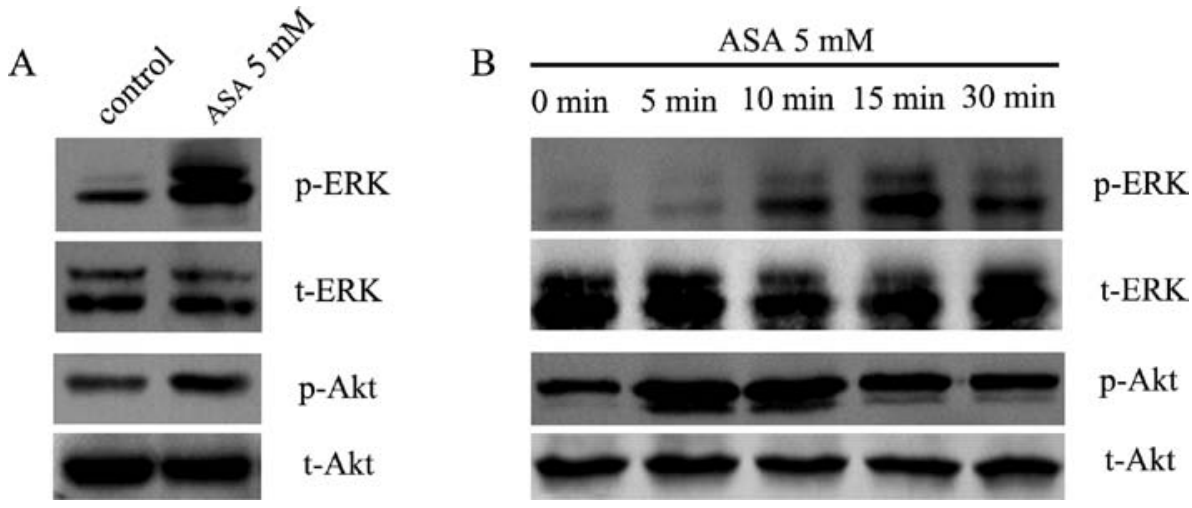

Figure 2. Effects of aspirin (ASA) on the activity of Akt and ERK1/2. (A) The phosphorylation levels of Akt (ser473) and ERK1/2 (thr202/tyr204) were measured by Western blot analysis. (B) HepG2 cells were incubated with serum-free medium for $2 \mathrm{~h}$ and then treated with ASA for different lengths of time in the presence of $1 \%$ serum. The phosphorylation level of Akt and ERK1/2 were analyzed by Western blot analysis.

A

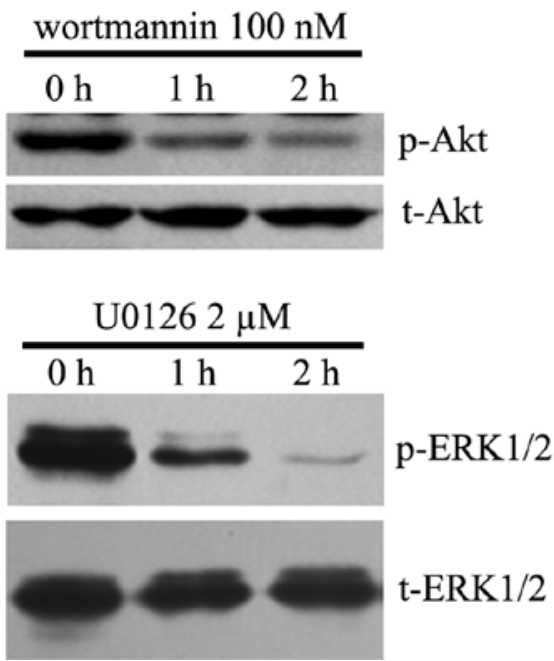

B

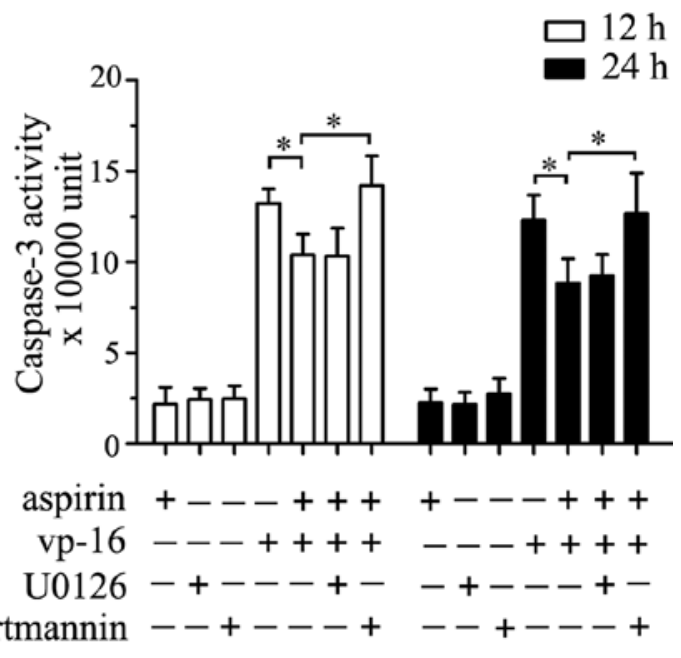

Figure 3. Effects of wortmannin and U0126 alone and in combination with aspirin and vp16 on caspase-3 acivity. (A) After treatment with wortmannin or U0126, the phosphorylation level of Akt (ser473) and ERK1/2(thr202/tyr204) were assayed by Western blot analysis. (B) After treatment, caspase-3 activity was determined by ELISA. The data are presented as the mean $\pm \mathrm{SE}$ of three independent experiments. (t-test, $\left.{ }^{*} \mathrm{P}<0.05\right)$

effect of ASA was dependent on the activation of Akt or ERK. The effects of wortmannin and U0126 on Akt and ERK activity were assessed by Western blot analysis (Fig. 3A). After treatment with $100 \mathrm{nM}$ wortmannin or $2 \mu \mathrm{m}$ U0126 for $1 \mathrm{~h}$, cells were incubated with ASA for another $1 \mathrm{~h}$ followed by the addition of vp16 into the medium. After culturing for another 11 and $23 \mathrm{~h}$, caspase- 3 activity was assayed. The data demonstrate that wortmannin abrogated the ASA-induced caspase-3 activity reduction whereas U0126 did not (Fig. 3B). These results suggest that ASA reduced the anti-cancer effect of vp16 mainly through the activation of Akt but not of ERK1/2.

Aspirin induces p2 $I^{\text {cip }}$ up-regulation via activation of Akt. Previous data have indicated that the anti-apoptotic effect of ASA is probably dependent on its cell cycle modulation. Therefore, some important cell cycle regulators, such as p53, p27 and p21 cip, were measured by Western blot analysis. The results indicated that ASA up-regulated the protein level of p2 $1^{\text {cip }}$ but not of p53 or p27 (Fig. 4A). However, ASA had little effect on the transcription level of p21 $1^{\text {cip }}$ (Fig. 4B). Regardless of the presence or absence of vp16, ASA enhanced the $\mathrm{p} 21^{\text {cip }}$ protein level and the activity of Akt (Fig. 4C). In order to determine whether this change of $\mathrm{p} 21^{\text {cip }}$ was dependent on the activation of Akt, wortmannin was used to inhibit the activation of Akt. The increase of $\mathrm{p} 21^{\text {cip }}$ induced by ASA was thoroughly abolished (Fig. 4D). Considering that the stability of $\mathrm{p} 21^{\text {cip }}$ is directly regulated by Akt through phosphorylation of ser146, the phosphorylation levels of ser146 p21 $1^{\text {cip }}$ were examined. The data showed that the ser146 phosphorylation levels of $\mathrm{p} 21^{\text {cip }}$ were up-regulated after treatment with ASA (Fig. 4E). Phosphorylating p21 $1^{\text {cip }}$ on ser146 can enhance its stability and inhibit its degradation (16). We therefore, deduce that ASA was able to increase the protein level of $\mathrm{p} 21^{\text {cip }}$ via activation of Akt which in turn stabilized $\mathrm{p} 21^{\mathrm{cip}}$ and inhibited its degradation through phosphorylation on ser146.

The anti-apoptotic effect of aspirin partly depends on $p 21^{\text {cip }}$ up-regulation. To verify whether ASA protects HepG2 cells against the vp16-induced apoptosis via increasing the expression of in $\mathrm{p} 21^{\text {cip }}$, the $\mathrm{p} 21^{\text {cip }}$ expression was reduced by small interference RNA (Fig. 5A). After down-regulating $\mathrm{p} 21^{\text {cip }}$ expression, cells were treated with vp16 of ASA 
A

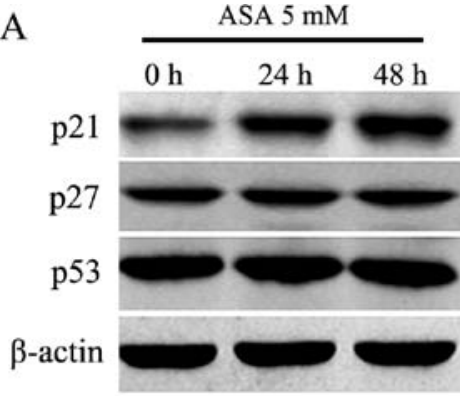

B

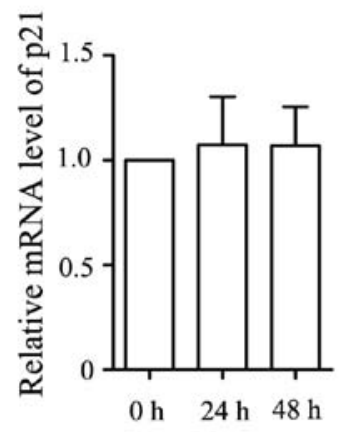

D ASA U0126 wortmannin

p21

$\beta$-actin

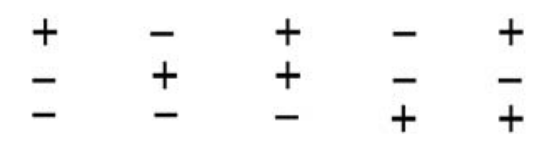

E
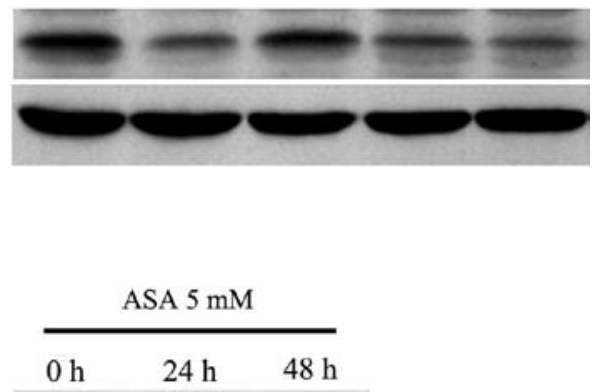

p-ser146-p21

$\beta$-actin
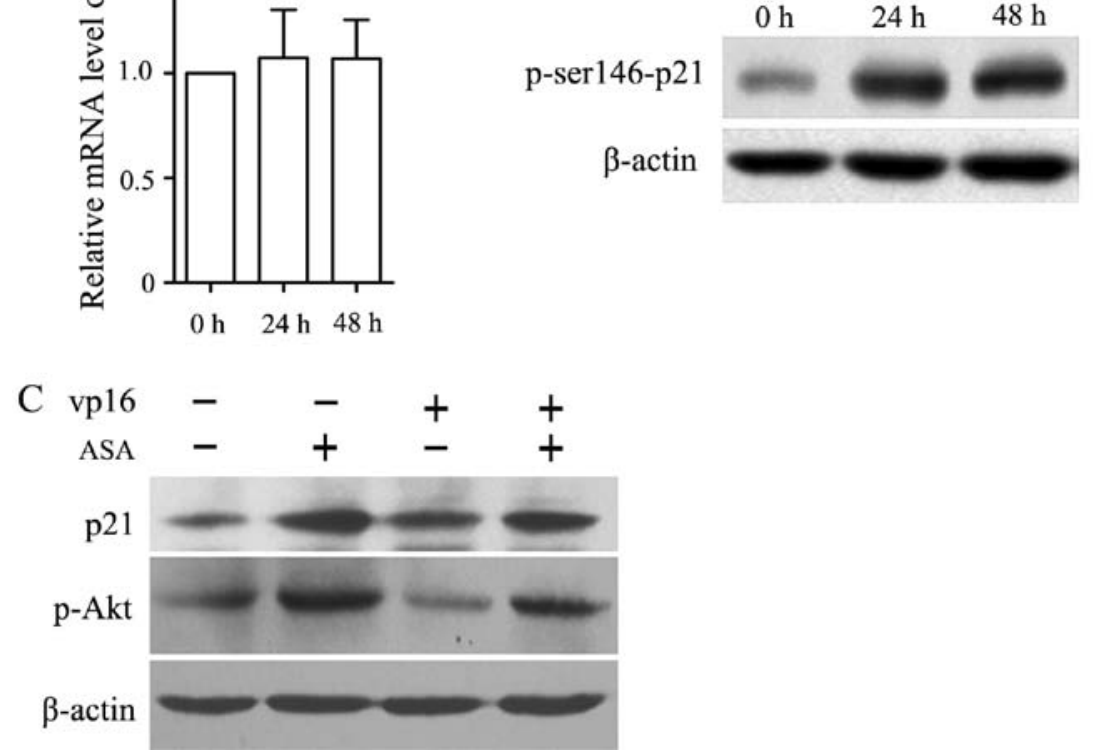

Figure 4. Protein up-regulation of $\mathrm{p} 21^{\text {cip }}$ is dependent on the activation of Akt. (A) Cells were treated with aspirin (ASA) for 24 or $48 \mathrm{~h}$ in $1 \%$ serum medium. p21, p27 and p53 protein levels were examined by Western blot analysis. (B) Cells were treated as above and the mRNA level of p21 cip was assayed by realtime PCR. Results were normalized to the control group. (one-way ANOVA, $\left.{ }^{*} \mathrm{P}<0.05\right)$. (C) After treated with aspirin (5 mM) and vp16 (20 $\left.\mu \mathrm{M}\right)$ alone and in combination, the p $21^{\text {cip }}$ protein level and phosphorylated Akt level were tested. (D) After treatment with wortmannin, U0126 and aspirin (5 mM) alone and in combination, p21 protein levels were examined by Western blot analysis. (E) The phosphorylated ser146 level of p21 assayed by Western blot analysis after aspirin $(5 \mathrm{mM})$ treatment.

alone and in combination. Cell apoptosis was evaluated by caspase-3 activity. Caspase-3 activity was significantly up-regulated in ASA + vp16 + siRNA-p21 $1^{\text {cip }}$ group compared to ASA + vp16 + siRNA-NC group (Fig. 5B). In addition, the caspase-3 activity was lower in ASA + vp16 + siRNA-p21 $1^{\text {cip }}$ group than it in vp16 + siRNA-NC group. In conclusion, reduction of $\mathrm{p} 21^{\mathrm{cip}}$ expression partially attenuated the antiapoptotic effect of ASA.

\section{Discussion}

Aspirin has multiple COX-independent effects and is involved in various cellular processes such as apoptosis $(10,12)$. On one hand, aspirin induces cell apoptosis via diverse pathways. On the other hand, aspirin can protect the cells from toxic stimuli inducing apoptosis/death (17-23). Therefore, the effect of aspirin on cell apoptosis is still unclarified. In this study, we observed that aspirin did not induce HepG2 cell apoptosis but it reduced the apoptotic effect of vp16. Meanwhile, aspirin induced cell cycle arrest and inhibited cell proliferation.

The PI3-K/Akt and ras/ERK-MAP kinase pathways are two essential pathways involved in cell motility, growth, proliferation, apoptosis, cell cycle and survival $(24,25)$. Akt and ERK1/2 are the key molecules in these two pathways. A study on the mouse fibrosarcoma model indicates that aspirin could induce Akt activation in vivo (26). Our data show that both Akt and ERK1/2 activity were greatly enhanced after long-time treatment with aspirin. Acute treatment experiments indicate that aspirin activated Akt and ERK1/2 instantly. Blocking Akt activation by the PI3-K selective inhibitor, wortmannin, abrogated the reduction of caspase-3 activity induced by aspirin. However, the ERK1/2 selective inhibitor did not alter the caspase-3 activity. Several studies suggest that inhibiting ERK1/2 activity could protect the cells from apoptosis (17). Taken together, we deduce that activation of Akt played the major role in the ASA reduction of the apoptotic effect of vp16.

Akt can regulate the cell cycle by enhancing the transcription of cell cycle regulators and modulating their stability directly or indirectly through phosphorylation on specific sites (16,27-29). Consistent with the previous study, we observed that ASA induced HepG2 cell accumulation in the G0/G1 phase. Our data demonstrate that aspirin up-regulated p2 $1^{\text {cip }}$ but not $\mathrm{p} 27$ or p53. However, aspirin had little effect 
A $\mathrm{p} 21$

$\beta$-actin

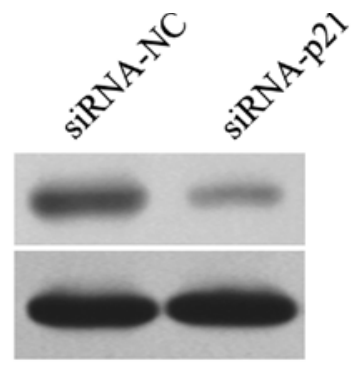

B

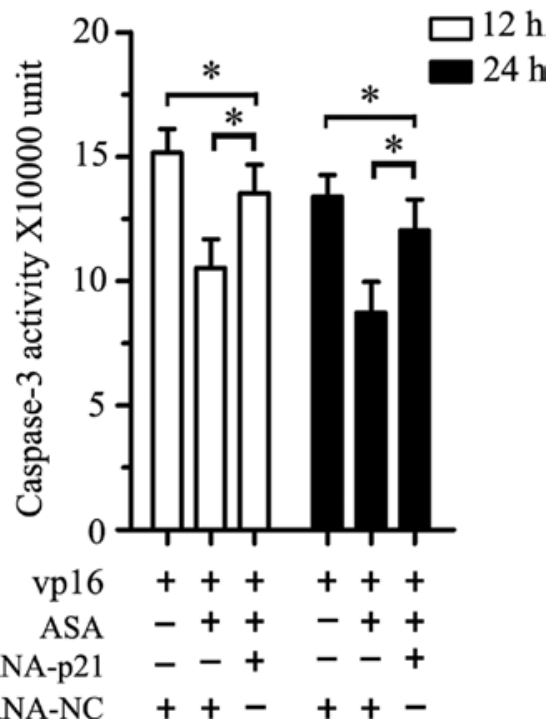

Figure 5. Reduction of $\mathrm{p} 21^{\text {cip }}$ expression attenuates the anti-apoptotic effect of aspirin (ASA). (A) After transfecting with siRNA-negtive control (siRNA-NC) and siRNA-p21 for $24 \mathrm{~h}, \mathrm{p} 21^{\text {cip }}$ protein levels were examined (B) Sliencing p21 expression as above, cells were treated with ASA or vp16 alone and incombination as above. Caspase- 3 activity was analyzed by ELISA after treatment ( ${ }^{*}$ t-test, $\left.\mathrm{P}<0.05\right)$.

on $\mathrm{p} 21^{\text {cip }}$ transcription. $\mathrm{p} 21^{\text {cip }}$, serves as an important cell cycle regulator, can modulate cell cycle by binding with the proliferating cell nuclear antigen (PCNA) and inducing cell arrest at the G1 phase (30). Moreover, p21 $1^{\text {cip }}$ can inhibit procaspase-3 activation and cell apoptosis through its binding with procaspase-3 (31). Akt can increase the binding between $\mathrm{p} 21^{\text {cip }}$ and its substrates via phosphorylating $\mathrm{p} 21^{\text {cip }}$ on ser146 (16). In our study, the ser146 phosphorylation levels of $\mathrm{p} 21^{\mathrm{cip}}$ were significantly enhanced in the aspirin-treated group. The aspirin-induced $\mathrm{p} 21^{\text {cip }}$ up-regulation was thoroughly abrogated by wortmannin but not by U0126. Reducing $\mathrm{p} 21^{\text {cip }}$ expression by siRNA attenuated the reduction of caspase-3 activity induced by aspirin in our experiments. Additionally, Akt can block caspase-3 activation via inhibiting the proapoptotic effect of caspase- 9 and Bad by phosphorylating ser196 and ser136 respectively $(32,33)$. Moreover, GSK-3, another substrate of Akt, regulates its downstream signaling, including the cytochrome $\mathrm{c}$ and caspase-3 pathways (34).

In brief, aspirin protected HepG2 cells from vp16 inducing apoptosis mainly through the activation of Akt. Activated Akt in turn phosphorylated $\mathrm{p} 21^{\text {cip }}$ at ser146. Phosphorylation of $\mathrm{p} 21^{\text {cip }}$ resulted in $\mathrm{p} 21^{\text {cip }}$ protein up-regulation by increasing its stability and inhibiting its degradation. This alteration of p2 $1^{\text {cip }}$ increased its binding with procaspase- 3 and by inhibiting procaspase- 3 cleavage. Therefore, these findings could be relative to the clinical condition where therapeutic schedules involving both high doses of aspirin and cytotoxic agents are needed, indicating that co-treatment with aspirin could reduce the outcome of anticancer therapy.

\section{Acknowledgements}

This study was supported by grants from the National Natural Science Foundation of China (30670999, 30770854, 30900501, 30871197, 2002CB713703) and the Shanghai Science and Technology Commission (08JC1403200).

\section{References}

1. Coleman WB: Mechanisms of human hepatocarcinogenesis. Curr Mol Med 3: 573-588, 2003.

2. Bruix J, Boix L, Sala M and Llovet JM: Focus on hepatocellular carcinoma. Cancer Cell 5: 215-219, 2004.

3. Koga H, Sakisaka S, Ohishi M, Kawaguchi T, Taniguchi E, Sasatomi K, Harada M, Kusaba T, Tanaka M, Kimura R, Nakashima Y, Nakashima O, Kojiro M, Kurohiji T and Sata M: Expression of cyclooxygenase-2 in human hepatocellular carcinoma: relevance to tumor dedifferentiation. Hepatology 29: 688-696, 1999.

4. Bae SH, Jung ES, Park YM, Kim BS, Kim BK, Kim DG and Ryu WS: Expression of cyclooxygenase-2 (COX-2) in hepatocellular carcinoma and growth inhibition of hepatoma cell lines by a COX-2 inhibitor, NS-398. Clin Cancer Res 7: 1410-1418, 2001.

5. Chan AT, Ogino S and Fuchs CS: Aspirin and the risk of colorectal cancer in relation to the expression of COX-2. N Engl J Med 356: 2131-2142, 2007.

6. Van Dyke AL, Cote ML, Prysak G, Claeys GB, Wenzlaff AS and Schwartz AG: Regular adult aspirin use decreases the risk of non-small cell lung cancer among women. Cancer Epidemiol Biomarkers Prev 17: 148-157, 2008

7. Slattery ML, Curtin K, Baumgartner R, et al: IL6, aspirin, nonsteroidal anti-inflammatory drugs, and breast cancer risk in women living in the southwestern United States. Cancer Epidemiol Biomarkers Prev 16: 747-755, 2007.

8. Lu M, Strohecker A, Chen F, et al: Aspirin sensitizes cancer cells to TRAIL-induced apoptosis by reducing survivin levels. Clin Cancer Res 14: 3168-3176, 2008.

9. Xu XM, Sansores-Garcia L, Chen XM, Matijevic-Aleksic N, Du M and Wu KK: Suppression of inducible cyclooxygenase 2 gene transcription by aspirin and sodium salicylate. Proc Natl Acad Sci USA 96: 5292-5297, 1999.

10. Dikshit P, Chatterjee M, Goswami A, Mishra A and Jana NR: Aspirin induces apoptosis through the inhibition of proteasome function. J Biol Chem 281: 29228-29235, 2006.

11. Pillinger MH, Capodici C, Rosenthal P, et al: Modes of action of aspirin-like drugs: salicylates inhibit Erk activation and integrin-dependent neutrophil adhesion. Proc Natl Acad Sci USA 95: 14540-14545, 1998.

12. Dong Z, Huang C, Brown RE and Ma WY: Inhibition of activator protein 1 activity and neoplastic transformation by aspirin. J Biol Chem 272: 9962-9970, 1997.

13. Yin MJ, Yamamoto Y and Gaynor RB: The anti-inflammatory agents aspirin and salicylate inhibit the activity of $I$ (kappa)B kinase-beta. Nature 396: 77-80, 1998.

14. Kopp E and Ghosh S: Inhibition of NF-kappa B by sodium salicylate and aspirin. Science 265: 956-959, 1994.

15. Gao H, Jin S, Song Y, et al: B23 regulates GADD45a nuclear translocation and contributes to GADD45a-induced cell cycle G2-M arrest. J Biol Chem 280: 10988-10996, 2005.

16. Li Y, Dowbenko D and Lasky LA: AKT/PKB phosphorylation of p21Cip/WAF1 enhances protein stability of p21Cip/WAF1 and promotes cell survival. J Biol Chem 277: 11352-11361, 2002.

17. Grilli M, Pizzi M, Memo M and Spano P: Neuroprotection by aspirin and sodium salicylate through blockade of NF-kappaB activation. Science 274: 1383-1385, 1996.

18. Kutuk $\mathrm{O}$ and Basaga $\mathrm{H}$ : Aspirin prevents apoptosis and NF-kappaB activation induced by $\mathrm{H}_{2} \mathrm{O}_{2}$ in HeLa cells. Free Radic Res 37: 1267-1276, 2003.

19. Hsu CS and Li Y: Aspirin potently inhibits oxidative DNA strand breaks: implications for cancer chemoprevention. Biochem Biophys Res Commun 93: 705-709, 2002. 
20. Shi X, Ding M, Dong Z, et al: Antioxidant properties of aspirin: characterization of the ability of aspirin to inhibit silica-induced lipid peroxidation, DNA damage, NF-kappaB activation, and TNF-alpha production. Mol Cell Biochem 199: 93-102, 1999.

21. Chen N, Ma WY and Dong Z: Inhibition of arsenite-induced apoptosis by aspirin. Anticancer Res 21: 3247-3251, 2001.

22. Sairam K, Saravanan KS, Banerjee R and Mohanakumar KP Non-steroidal anti-inflammatory drug sodium salicylate, but not diclofenac or celecoxib, protects against 1-methyl-4-phenyl pyridinium-induced dopaminergic neurotoxicity in rats. Brain Res 966: 245-252, 2003.

23. Mattie MD and Freedman JH: Protective effects of aspirin and vitamin E (alpha-tocopherol) against copper- and cadmiuminduced toxicity. Biochem Biophys Res Commun 285: 921-925, 2001.

24. Cantley LC: The phosphoinositide 3-kinase pathway. Science 296: 1655-1657, 2002.

25. Sussman M: 'AKT'ing lessons for stem cells: regulation of cardiac myocyte and progenitor cell proliferation. Trends Cardiovasc Med 17: 235-240, 2007.

26. di Palma A, Matarese G, Leone V, et al: Aspirin reduces the outcome of anticancer therapy in Meth A-bearing mice through activation of AKT-glycogen synthase kinase signaling. Mol Cancer Ther 5: 1318-1324, 2006.

27. Zhou BP, Liao Y, Xia W, et al: HER-2/neu induces p53 ubiquitination via Akt-mediated MDM2 phosphorylation. Nat Cell Biol 3: 973-982, 2001.
28. Ogawara Y, Kishishita S and Obata T: Akt enhances Mdm2mediated ubiquitination and degradation of p53. J Biol Chem 277: 21843-21850, 2002

29. Kim SW, Kim HJ, Chun YJ, et al: Ceramide produces apoptosis through induction of $\mathrm{p} 27$ (kip1) by protein phosphatase 2A-dependent Akt dephosphorylation in PC-3 prostate cancer cells. J Toxicol Environ Health A 73: 1465-1476, 2010.

30. Cayrol C, Knibiehler $M$ and Ducommun B: p21 binding to PCNA causes G1 and G2 cell cycle arrest in p53-deficient cells. Oncogene 16: 311-320, 1998.

31. Suzuki A, Ito T, Kawano H, Hayashida M, Hayasaki Y, Tsutomi Y, Akahane K, Nakano T, Miura M and Shiraki K: Survivin initiates procaspase 3/p21 complex formation as a result of interaction with Cdk4 to resist Fas-mediated cell death. Oncogene 19: 1346-1353, 2000.

32. Cardone MH, Roy N, Stennicke HR, et al: Regulation of cell death protease caspase-9 by phosphorylation. Science 282: 1318-1321, 1998.

33. Wu W, Lee WL, Wu YY, et al: Expression of constitutively active phosphatidylinositol 3-kinase inhibits activation of caspase 3 and apoptosis of cardiac muscle cells. J Biol Chem 275: 40113-40119, 2000.

34. Koh SH, Kim SH, Kwon H, et al: Epigallocatechin gallate protects nerve growth factor differentiated PC12 cells from oxidative-radical-stress-induced apoptosis through its effect on phosphoinositide 3-kinase/Akt and glycogen synthase kinase-3. Brain Res Mol Brain Res 118: 72-81, 2003. 